\title{
Six Days War that Changed the Middle East
}

\author{
Ali MS ${ }^{1,2 *}$, James $\mathbf{M}^{1}$ \\ ${ }^{1}$ School of Humanities and Sociology, Nottingham Trent University, Nottingham, UK \\ ${ }^{2}$ National University, Bangladesh
}

*Corresponding Author: Ali MS, School of Humanities and Sociology, Nottingham Trent University, Nottingham, UK \& National University, Bangladesh.Email: md.national.u@ gmail.com

\begin{abstract}
The Six-Day War was a short but bloody war between Israel and Egypt, Syria and Jordan in June 1967. Following quite a while of strategic rubbing and honing among Israel and its neighbors, Israel Defense Forces propelled preventive air strikes that disabled Egypt's flying corps and their partners. Israel at that point organized an effective ground hostile and held onto the Sinai Peninsula and the Gaza Strip from Egypt, the West Bank and East Jerusalem from Jordan, and the Golan Heights from Syria. The concise war finished with a U.N. - handled truce, however it altogether modified the guide of the Mideast and offered ascend to waiting geopolitical rubbing.
\end{abstract}

Keywords: Middle East, Israel, Palestine, Six Day War.

\section{INTRODUCTION}

In this article, we will discuss one of the most important issues in history, namely the dispute between Israel and Palestine. There is no doubt that the conflict between Israel and Palestine has affected a large part of the Middle East and the Arab world. The Palestinian people have had many problems since the creation of the state of Israel that came about with the help of the United Nations, primarily from the West. Most Palestinians have been forced to flee, leaving Palestine. Those who were inside Palestine were able to organize themselves to fight Israel. This organization among Palestinians was particularly evident to the whole world after the 1967 war. The Palestinian community was in a deep crisis after the stunning victory of Israel over the Arabs, in particular, a victory over the Arab nationalist ideology [1-2]. The Palestinians have been pushed into their own hands because they have lost hope of an Arab liberation in Palestine. In the mid-60s until the end of the 80s, it was the nationalist and Marxist-oriented movement that fought against Israel. However, when the Berlin Wall fell and the Soviet Union began disintegrating, Marxist organizations lost their influence, they then disappeared from the Palestinian struggle. From the beginning of the 90 s, the Islamist movements grew in significance, and began to exacerbate the situation. The Islamic movements have been a major force in Palestinian society ever since and they have now reached the position that, without them, an agreement with the Israelis cannot be reached. Now after 60 years, the Palestinians remain without land and a viable state and appear to be making little progress [3-4]. On the other side of the conflict, however, Israel grew into a regional superpower after the 1967 war, and the small state would in a very short time kill the Arab nationalist dream. Israeli society largely supported the occupation of Gaza and the West Bank at the beginning of the conflict and they would not see the consequences of this occupation until the mid-90s and up to early 2000. After Israel was hit by a series of suicide bombings perpetrated by Palestinians from the new generation who grew up under occupation, the Israelis began to demand their troops withdrawn from the occupied territories, and Israeli society was also willing to recognise a Palestinian State for the first time [5-9]. In six days during June 1967, the Israeli military devastated the air and ground forces of Egypt, Syria, and Jordan and occupied Sinai, the Gaza Strip, the Golan Heights, and the West Bank (an area west of the Jordan River), including East Jerusalem. The Six-Day War established Israel as the premier military power in the Middle East [10-11]. This conflict also strengthened the US-Israeli relationship when America recognized Israel as imperative significant asset in its Cold War struggles. According to Sheldon L. Richman the Six-day war was also reason for the strengthening relation between U.S. and Israel. The war was therefore not only between the Arab armies and Israel, but also between pro-Soviet countries 
like Egypt and Syria and pro-American countries like Israel. Superpowers had a significant role in the conflict between Israel and Palestine and they had an interest in supplying both sides in order to be able to involve themselves in a conflict by proxy. The loss of the Palestinian-Marxist movements can be explained by the fact that these movements, after the Soviet Union's dissolution, lost their ideological and financial support and were replaced with the Islamic movements, with support from Iran and Saudi Arabia. The study will focus primarily on the implications for Palestine and Israel populations of the Six-Day War and how this war impacts the Palestinian resistance movement in particular [12]. There are many reports published related on Arab-Israel conflicts. This study will try to describe shortly and concisely of the matter.

\section{MeThodologY}

Some of the popular war literatures, journals and books relevant to the war are the basis of this paper.

\section{RESULTS AND DISCUSSION}

\subsection{Pan Arabism}

The 1967 overcome unleashed an unprecedented quest for soul among the Middle East and others who had lived the vision promoted by the democratic administrations of the Middle East. Everything was questioned-politics, philosophy, culture, and religion-in arrange to get it the reasons behind the vanquish. In specific, the Egyptian and Syrian administrations and the beliefs that they stood for were the objects of study and feedback [2]. The Six-Day War was one of the foremost vital occasions that have taken put within the Middle East and was a turning point for the complete locale. This war has given rise to numerous diverse changes in both the Middle east and Israeli communities. For the Middle east, the war was not as it were a military disappointment but was moreover a misfortune to Middle East patriotism and the dream of a incredible Middle east country [13-14]. This war affected the whole world, and both intellectual and committed pioneers were shocked and do not seem to find answers to the awful misfortunes of the war and the rapid deceit of pan-Arabism. The Middle east were beneath a awesome bargain of weight and yearned for exact retribution and a assist chance to assault the Israelis. Thus, the Middle east started to reexamine Middle east patriotism, and their scorn against the Jews and Zionism developed. Another critical result of this war was that two major patterns which happened among Middle east knowledge; specifically common and Islamic knowledge. The ruin of Middle East nationalism and the rise of Islamist belief system within the Middle East community made individuals see Islam as an elective. It was a brief description of the consequences of the 1967 war for the ideology of democracy in the Middle East, but I will see the effects of the SixDay War for Palestinians and Israelis in particular. The clashes between Palestinians and Israelis have not only affected them, but the complete Center East. As specified prior the Six-Day war was a turning point for both the Israelis and Middle east and numerous of today's clashes result from this brief war. We will to begin with perform a brief audit of the 1967 war's result. Within the to begin with portion of the task, we see at the run-up to the war, the casualties of the war and the UN's part within the strife. In the portion of the moment, we see the outcome of the war on relations between Israel and the Middle East [15-16].

\subsection{War}

In June 1967, war broke out within the Center East between the Israeli and Middle Eastern Armed Forces, and it was not the main or final demonstration at the site. The Israelis and Middle easts had as of now been at war against each other in 1948 and 1956. A period of rising military control had taken put some time recently the episode of the war in 1967. Egypt may, with Soviet offer assistance, construct up a solid armed force whereas the Israelis had the Center East's best-trained and most advanced armed force. On the 16th May, Nasser requested the UN peacekeeping powers to take off Sinai and on the 22nd May Nasser blocked the Aqaba Inlet. It was an awfully provocative act, which successfully anticipated Israeli ships from entering through the Tiran Straits. Israel deciphered this as a clear affirmation of war and started to get ready a counter assault [17]. On 5 June 1967, early in the morning, a pre-emptive Israeli airstrike wiped out Egypt's capacity to discuss. Most Egyptian aircrafts were annihilated on the ground some time recently they got a chance to require off. Afterward within the day, the Israelis moreover crushed the Jordanian, Syrian, and Iraqi discuss strengths. Israel won a pulverizing triumph over the Egyptian, Syrian, and Jordanian strengths, changing its status from a little state to a regional superpower. Over the six-day period, the Middle east powers misplaced 
thousands warriors additionally the war. Israel had prevailed ranges of the Sinai Promontory, the West Bank, Gaza, and Golan Statures. Israel's borders were extended to three and a half times their unique size. In any case, following recommendations from the UN, Israel did not withdraw from the regions involved. The UN Security Council reiterated Determination 242 on 22 November 1967. The determination communicates concern around the circumstance within the Middle East and the ought to work for a fair and enduring peace in which all nations can live in security. The reasonable and enduring peace ought to be based on three conditions- the withdrawal of Israeli outfitted powers from the possessed territories; Respect for and acknowledgment of any sovereignty; A arrangement to the Palestinian displaced person problem [18-19]. The Middle East was willing to build peace with Israel and to perceive the right of Israel to exist, but as it were after the Israelis had withdrawn from the dominant Middle East. The Israelis, in turn, announced their availability to pull back from the involved regions, but demanded that the Middle easts ought to to begin with recognize Israel's presence and make peace so that withdrawals and the outcast issue may well be negotiated. Israel would utilize the involved regions as ensure for peace, that's to say, as a haggling chip: arrive for peace step by step [20-24]. The war changed the control adjust within the Center East. It was presently clear that Israel was militarily more grounded than any of the Middle east nations, and it changed the Middle east countries' political and financial relations with the exterior world [1-4].

\section{CONClusion}

The final phase of the fighting took place on the northeastern border of Israel with Syria. After an intense aerial bombardment on 9 June, Israeli tanks and infantry advanced into a heavily fortified region of Syria called the Golan Heights. The next day, they took the Golan successfully. A truce brokered by the United Nations came into effect on 10 June 1967 and the Six-Day War came to an abrupt end. Around 20,000 Arabs and 800 Israelis were later believed to have died in just 132 hours of fighting. The Arab leaders were stunned by the severity of their defeat. Egyptian President Nasser even resigned in disgrace to return to office promptly after massive street demonstrations by Egyptian citizens showed their support. The national mood in Israel was jubilant. The young nation captured Egypt's Sinai Peninsula and Gaza Strip in less than a week, Jordan's West Bank and East Jerusalem, and Syria's Golan Heights.

\section{REFERENCES}

[1] Bickerton, I. J., \& Klausner, C. L. (2018). A history of the Arab-Israeli conflict. Routledge.

[2] Lesch, D. W. (2018). The Arab-Israeli conflict: a history. Oxford University Press.

[3] Gerges, F. A. (2018). The 1967 Arab-Israeli War: US Actions and Arab Perceptions. In The Middle East and the United States (pp. 139-157). Routledge.

[4] Smith, C. D. (2001). Palestine and the Arab-Israeli conflict. Bedford/St. Martin's.

[5] Quandt, W. B. (1977). Decade of decisions: American policy toward the Arab-Israeli conflict, 1967-1976. Univ of California Press.

[6] Quandt, W. B. (2010). Peace process: American diplomacy and the Arab-Israeli conflict since 1967. Brookings Institution Press.

[7] Podeh, E. (2002). The Arab-Israeli conflict in Israeli history textbooks, 1948-2000 (p. 89). Westport, CT: Bergin \& Garvey.

[8] Landau, J. M., \& Landau, J. M. (1993). The Arab minority in Israel, 1967-1991: political aspects (p. 101). Oxford: Clarendon Press.

[9] Harms, G., \& Ferry, T. M. (2017). Palestine-israel Conflict. London: Pluto Press.

[10] Oren, N. (2009). The Israeli ethos of conflict 1967-2006.

[11] Laqueur, W. (1968). The road to war, 1967: the origins of the Arab-Israel conflict. Weidenfeld \& Nicolson

[12] Miller, A. D. (1987). The Arab-Israeli Conflict, 1967-1987: A Retrospective. Middle East Journal, 41(3), 349.

[13] Neff, D. (1994). Israel-Syria: conflict at the Jordan river, 1949-1967. Journal of Palestine studies, 23(4), 26-40.

[14] Mansfeld, Y. (1994). The Middle East conflict and tourism to Israel, 1967-90. Middle Eastern Studies, 30(3), 646-667.

[15] Haddad, Y. (1992). Islamists and the" Problem of Israel": The 1967 Awakening. The middle east journal, 266-285.

[16] Kosut, H. (1968). Israel \& the Arabs: the June 1967 war (Vol. 2). Facts on File.

International Journal of History and Cultural Studies (IJHCS)

Page $\mid 9$ 
[17] Lukacs, Y. (Ed.). (1992). The Israeli-Palestinian Conflict: A Documentary Record, 1967-1990. Cambridge University Press.

[18] Gombos, G. M. (1969). Ocular War Injuries in Jerusalem: During the 1967 arab-israeli conflict. American journal of ophthalmology, 68(3), 474-478.

[19] Gilbert, M. (2005). The Routledge atlas of the Arab-Israeli conflict. Routledge.

[20] Newman, D. (1989). Civilian and military presence as strategies of territorial control: the Arab-Israel conflict. Political Geography Quarterly, 8(3), 215-227.

[21] O'Ballance, E. (1974). Arab guerilla power, 1967-1972. Faber \& Faber.

[22] Peters, J., \& Newman, D. (Eds.). (2013). The Routledge handbook on the Israeli-Palestinian conflict. Routledge.

[23] Shemesh, M. (2008). Arab Politics, Palestinian Nationalism and the Six Day War: the Crystallization of Arab Strategy and Nasir's Descent to War 1957-1967. Digest of Middle East Studies, 17(2), 66-69.

[24] Wilkenfeld, J., Lussier, V. L., \& Tahtinen, D. (1972). Conflict interactions in the Middle East, 1949-1967. Journal of Conflict Resolution, 16(2), 135-154.

Citation: Ali MS, James M. "Six Days War that Changed the Middle East". International Journal of History and Cultural Studies (IJHCS). vol 6, no. 1, 2020, pp. 7-10 doi: DOI: http://dx.doi.org/10.20431/24547654.0601002 .

Copyright: (c) 2020 Authors. This is an open-access article distributed under the terms of the Creative Commons Attribution License, which permits unrestricted use, distribution, and reproduction in any medium, provided the original author and source are credited. 